\title{
Dieting habits as a crucial factor for maintaining health in a student population
}

\section{Navike u ishrani kao važan faktor očuvanja zdravlja kod učeničke i studentske populacije}

\author{
Jasmina Djordjevic-Pesic ${ }^{1}$, Vladan Pesic ${ }^{2}$, \\ Goran Damnjanovic ${ }^{3}$ \\ 1. Medical School "Dr Milenko Hadzic", Nis, Serbia \\ 2. Department of Genetics, Faculty of Agriculture, University of Belgrade, \\ Belgrade, Serbia \\ 3. Military Hospital, Nis, Serbia \\ RECEIVED 05.01.2018. \\ ACCEPTED 18.05 .2018
}

\section{ABSTRACT}

Objective. Dietary habits influence different aspects of health, such as: subjective health assessment, life habits (such as physical activities), functional status, as well as the health care, where inadequate diet represents a significant risk factor for the formation of numerous, various health disorders. It is estimated that around $31 \%$ of children in the world under 5 is malnourished, while mortality caused by illness, hunger or malnutrition makes even $50 \%$ overall mortality in children. The basic aims of this research are to examine the dieting characteristics of pupils and students and the differences in these two groups' diet compared to their defined demographic and socio-economical features.

Methods. A cross-section study has been done on the sample of 480 pupils and students in Nis. The research in the field was performed between 20th November and 2nd December in 2014 (special days for certain groups of subjects). As previously mentioned, a statistical package computing program Statistical Package for Social Sciences (SPSS for Windows rel. 13.0) was used.

Results. The analysis shows that men have breakfast more rarely than women. The results are similar in answers to the question if they never have breakfast. Unlike the previous results, men have lunch more often than women and the answers to the question if they have an afternoon snack are similar. The difference is more apparent when it comes to afternoon snacks, men have lunch more often which is the same for the habit of having dinner or supper. An especially interesting question was the one whether subjects think about their health when they choose what to eat. The most frequent answer was that they consider it sometimes, a little less than a half or $45.2 \%$, every third respondent, $29.0 \%$, consider it often, and only every sixth does it always (16.3\%).

Conclusion. The most subjects sometimes thought about their health when they choose what to eat.

Key words: diet; food preferences; health; young adult; students.

\author{
Jasmina Đorđević-Pešić ${ }^{1}$, Vladan Pešić ${ }^{2}$, Goran \\ Damnjanović3 \\ 1. Medicinska škola „Dr Milenko Hadžić“, Niš \\ 2. Katedra za genetiku, Poljoprivredni fakultet, Univerzitet u Beogradu, Beograd \\ 3. Vojna bolnica, Niš
}

PRIMLJEN 05.01.2018.

PRIHVAĆEN 18.05.2018.

\section{APSTRAKT}

Cilj. Navike u ishrani utiču na više različitih aspekata zdravlja, između ostalih na subjektivnu ocenu zdravlja, druge životne navike (kao što je fizička aktivnost), funkcionalni status, ali i korišćenje zdravstvene zaštite, a nepravilna ishrana predstavlja značajan faktor rizika za nastanak brojnih različitih poremećaja zdravlja. Procenjuje se da je oko $31 \%$ dece u svetu do 5 godina stare pothranjeno, dok smrtnost usled bolesti gladi i pothranjenosti učestvuje čak sa $50 \%$ ukupnog mortaliteta kod dece. Osnovni ciljevi istraživanja su da se ispitaju karakteristike ishrane učenika i studenata, kao i da se ispitaju razlike u ishrani učeničke i studentske omladine u odnosu na definisana demografska i socioekonomska obeležja ispitanika.

Metode. Izvršena je studija preseka na uzorku od 480 učenika i studenata iz Niša. Terenski deo istraživanja sproveden je od 20. novembra do 02. decemba 2015. godine (posebni dani za određene grupe ispitanika). Korišćen je statistički paket-računarski program Statistical Package for Social Sciences (SPSS for WIndows rel. 13.0).

Rezultati. Analiza pokazuje da muškarci ređe doručkuju u odnosu na osobe ženskog pola. Odgovori su jedino približni na pitanje da li nikada ne doruckuju Za razliku od prethodnih rezultata muškarci redovnije ručavaju, a slični su odgovori u odnosu na to da li imaju poslepodnevnu užinu. U ostalim situacijama može se reći da devojke vode više računa o svom zdravlju. Posebno je bilo interesantno pitanje da li ispitanici pri izboru načina ishrane razmišljaju o svom zdravlju. Najučestalije izjašnjavanje bilo je da razmišljaju ponekad, nešto manje od polovine ili $45.2 \%$ često, svaki treći ispitanik ili 29.0\%, a uvek, tek svaki šesti (16.3\%).

Zaključak. Većina ispitanika ponekad razmišlja o svom zdravlju kada bira šta da jede

Ključne reči: ishrana; prioriteti namirnica; zdravlje; mladi; studenti. 


\section{INTRODUCTION}

One of the most important exogenous determinant of human health is their diet. A healthy diet is one of the most important health resources, crucial for lifting health potential on individual level and on the level of the whole community. Dieting habits of Serbian population, children and youth, are characterized by irregular meals, small intake of fruit and vegetables, with high intake of the food with high energy density. As a consequence, there is a growing number of overweight and obese children, i.e.21.8\% of overweight children and young adults aged between 15-24 .${ }^{1,2}$ Culture and customs, family and social background, as well as the availability of food represent a great importance , not only regarding the choice of groceries but also the order of meals during the day and the way of preparing food. Dietary habits influence different aspects of health such as : a subjective estimation of health, other life habits (such as physical activities), functional status, as well as the health care, where inadequate diet represents a significant risk factor for the formation of numerous, various health disorders. ${ }^{3,4}$ Additionally, a great number of people in the world, around 200 million, have different micro nutritious deficit, hence different forms of health disorders. ${ }^{5,6}$ It is estimated that around $31 \%$ of children in the world under the age of 5 is malnourished, while mortality caused by illness, hunger or malnutrition makes even $50 \%$ of overall mortality in children. ${ }^{7,8,9}$

In Serbia, in 2013, 93.8\% of children and adolescents had breakfast every day which is significantly higher than in 2006 (90\%). The share of children and youth from 7-14 who consume whole grain bread is minimal (3.5\%), and is significantly lower than in $2006(6 \%)$. There is a growing trend of children and youth consuming at least one glass of milk or dairy products every day, as well as those who use wholegrain bread in families with rising welfare index. The percentage of children who put salt on food without tasting it is 3.6\%. ${ }^{1,2}$ More than half of the children and adolescents (51\%) consumed fresh fruit every day, and this also applies to vegetables where more than half of them (56,6\%) in 2013. consummated fresh vegetables on a daily basis which has improved comparing to 2006.(48,9\%). In Serbia, in 2013, only $15.5 \%$ of children and teenagers from 7 to 14 followed content related to the health through media, which is similar to 2006 (13.8\%). The growth of number of moderately overweight and overweight children in Serbia is due to bad eating habits and insufficient physical activities which has become a significant national health issue..$^{10,11}$

Basic aims of this research are: a) to examine the dieting characteristics of pupils and students; b) to examine the differences in diets of pupils and students compared to defined demographic and socio economic features of the examined; c) based on these results to determine possible health disorders, as well as the needs related to health and educational intervention aiming to a promotion of the proper diet.

\section{SUBJECTS AND METHODS}

A cross-section study has been done on the sample of 480 pupils and students in Nis. The research in the field was performed between 20th November and 2nd December in 2015 (special days for certain groups of subjects). The basic group has been represented by the students of the University of Nis and the pupils from the Medical school "Dr Milenko Hadzic" from Nis. A group of the first and the third year students from the Faculty of Engineering and the second year students from the Faculty of Occupational Safety and Health in Nis has been observed as part of the basic set. 133 subjects or $27.7 \%$ out of overall 480 are the first year students from the Faculty of Engineering (further referred to as the first year students), 89 subjects are the third year students from the Faculty of Engineering (further referred as the third year students), 63 of them are students from the Faculty of Occupational Safety and Health (further referred to as the second year students) and 195 pupils from the Medical school "Dr Milenko Hadzic" from Nis (further referred to as the pupils from Nis). There are more female pupils and students among the subjects, $60.8 \%$ or 292 and 188 or $39.2 \%$ of male subjects.

Random selection method has been used to analyze pupils from high schools in Nis. Special questionnaires designed on the basis of relevant experiences and recommendations from similar researches in other countries have been used. For examining dieting characteristics of student and pupil population variables have been used referring to persons older than 18 (senior pupils from the Medical school in Nis). Therefore, statistical methods that have been used here were proportions, grouping and tables, aiming to calculate statistically significant differences ( $\chi 2$-test). Statistical tests with the probability of null hypothesis equal to or less than $5 \%(\mathrm{p}<0.05)$ were accepted. As previously mentioned a Package for Social Sciences (SPSS for Windows rel. 13.0) was used. 


\section{RESULTS}

Men have breakfast more rarely (37.0\%) than female $(60.3 \%)$. Female also sometimes have breakfast in twice as bigger percentage as men. Number of those who never have breakfast is similar. Female subjects (53.7) have snacks in the morning more often than male subjects (42.6\%), sometimes a difference is even bigger and in favor of female subjects $(58.8 \%)$ comparing to male peers (38.9\%) when it comes to question of whether they never have snacks in the morning. The number of women not doing it is almost double. $2.4 \%$ of women never have lunch, sometimes $15.4 \%$ and in $78.8 \%$ cases they do every day. Men have lunch more often than women $(82.0 \%)$, sometimes in $11.2 \%$ of the cases and never $3.4 \%$. Similar result in both groups is when it comes to afternoon snacks (Figure 1).

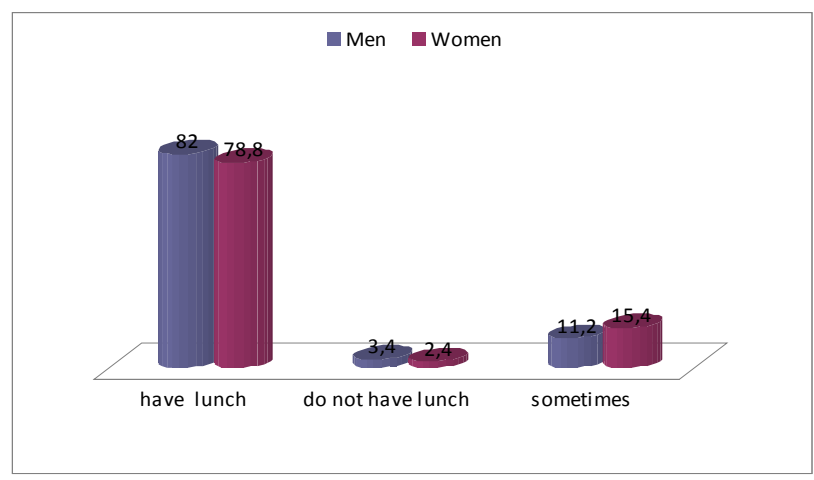

Figure 1. The meal frequency in men and women.

Men have dinner more often during the week, every day $70.8 \%$, of them comparing to women with $46.6 \%$. The situation is opposite to the question of having dinner sometimes. Here, the number of women is higher $37.3 \%$, than men $21.3 \%$. Three times more women (12.3\%) than men (3.4\%) never have dinner. When comparing eating habits of taking food in the late evening hours among different genders, there is a statistically significant difference $(\chi 2=29.846$; $\mathrm{p}=0.000)$.

When answering question whether they drink milk or not, yoghurt or sour milk, white coffee or hot cocoa, different genders do 'not show significant statistical difference. Every fifth subject has 2 or more glasses every day, one glass (35.6\%), sometimes (39.0\%) and never (1.9\%). Similar situation is with genders.

During the previous week subjects consummated potatoes in this manner: six to seven times - only $0.4 \%$ subjects, three to five times $-4.6 \%$, once or twice $-37.7 \%$ and never (51.9\%). If we expand this analysis on genders, there is no statistically significant difference. As far as the frequency of fried potatoes consumption is concerned during the previous week, the data show that a small number of subjects do it more often, six to seven times $-0.6 \%$, a bit more, three to five times $(10.0 \%)$, a bit less than a half have it once or twice a week $(49.6 \%)$, and never $-33.8 \%$. There is no statistically significant difference in terms of gender.

As far as the frequency of rice and pasta consumption is concerned in the previous week, a small number of subjects do it often, six to seven times a week $2.7 \%$, a bit more three to five times $(9.2 \%)$, less than a half do it once or twice a week and never $-34.2 \%$. There is no significant statistical difference in terms of gender. $19.2 \%$ subjects eat cheese six to seven times a week, 3 to 5 times $-31 \%$, once or twice $28.4 \%$ and never $14.4 \%$ of cases. There is no difference in gender (Figure 2).

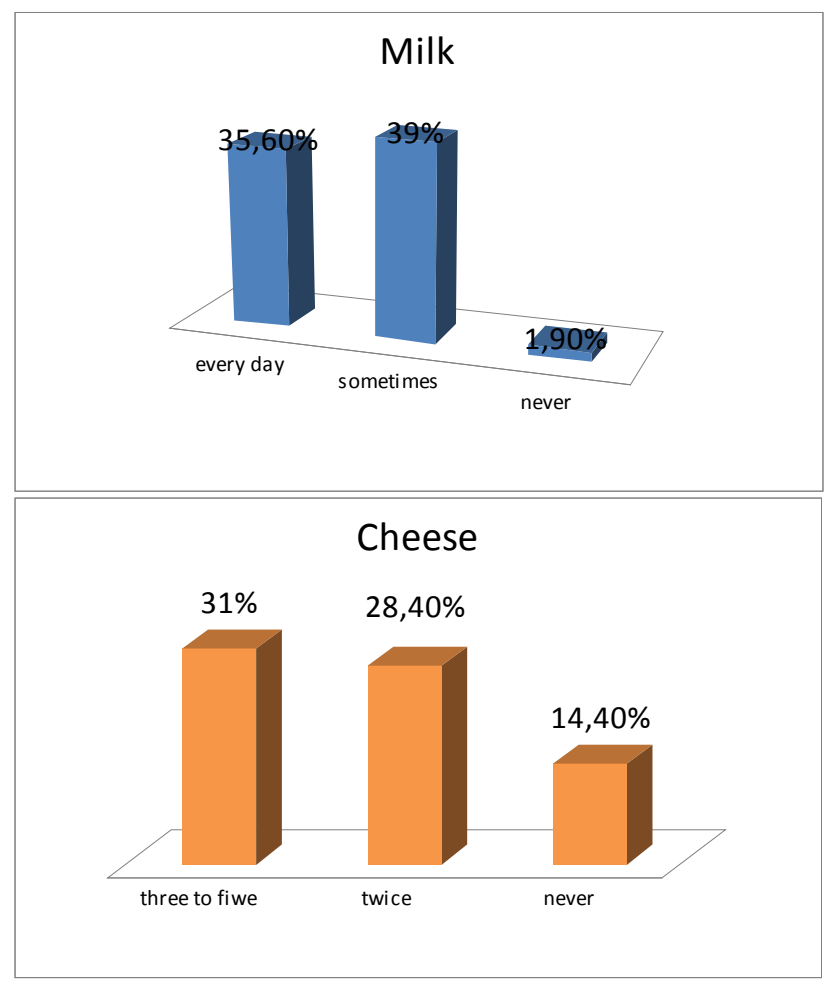

Figure 2. The frequency of milk and cheese consumption

During the last week chicken was consummated 6 to 7 times by $3 \%$ of subjects, three to five times by $-21.9 \%$, once to twice by $44.4 \%$ and never by $19.4 \%$. With the fish consummation the situation is following: six to seven times a week $2.5 \%$ of subjects, three to five times $7.3 \%$, once or twice a week $30.6 \%$ and never $51.3 \%$.

Pork has been consummated six to seven times by $-4.6 \%$ of subjects, $7.5 \%$ three to five times by $26.1 \%$, once or twice or never by $52.8 \%$. As far as beef consummation is concerned , the situation is the following: six to seven times have done it in $3.1 \%$ of the cases, $12.3 \%$ three to five times $28.8 \%$, once and twice observed by gender $(\chi 2=32.131 ; \mathrm{p}=0.000)$. Male subjects eat more beef, three to five times a week (16.3\%) compared to women $(9.6 \%)$, or never, where male subjects do it in $38.2 \%$ cases with $55.8 \%$ of women. 
Regarding meat products weekly intake among both genders, it is apparent that every ninth person does it every day, (11.3\%), three to five times, $26.0 \%$, once or twice $33.5 \%$ and never $-22.1 \%$. A statistically significant difference in gender has not been observed (Figure 3).

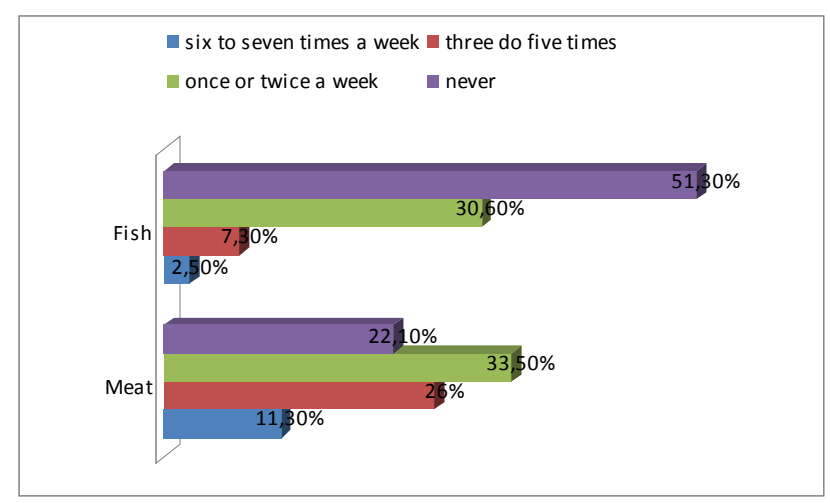

Figure 3. Meat and fish products intake

Fresh vegetables have been consummated by every third subject (29.8\%), with the same number of three to five times, a little less frequency has been registered when subjects do it once or twice (25.6\%) and never in $8.3 \%$ cases. A statistically significant difference has not been registered in terms of gender.

With fresh fruit consumption the situation was better. $37.7 \%$ have taken fruit six to seven times in the previous week. Three to five times in $28.5 \%$ of the cases, once or twice in $21.5 \%$ and never in $5.2 \%$ cases.

Sweet pastries (cakes and biscuits) have been consummated six to seven times a week by $24.8 \%$ subjects of both genders, three to five time by $28.8 \%$, once or twice in the previous week by $30.2 \%$ and never by every tenth subject (10.6\%).

Sweets, (candies, chocolate) have been taken b six to seven times by $26.9 \%$ subjects of both gender in the previous week, three to five by $24.4 \%$, once or twice by $28.8 \%$ or never every ninth person. There is no statistically significant difference in gender analysis. Sweet non alcohol drinks (Coca Cola, Sprite, Schweppes, hot chocolate) 27.5\% subjects drink six to seven times a week, three to five times $21.0 \%$, once or twice a week $23.1 \%$ and never $18.1 \%$ of subjects. A statistically significant difference has been registered in terms of gender: $(\chi 2=32.056 ; p=0.000)$.

Eggs are consummated six to seven times by $9.2 \%$ subjects, three to five times in $24.0 \%$ cases, once or twice in $43.3 \%$ and never in $17.5 \%$ cases. There is no statistically significant difference related to gender.

In the previous week $4.0 \%$ subjects haven 't used bread in their diet, different kinds of bread have used around 6\%, black-rye $17.1 \%$, half white $13.3 \%$ and white even $47.9 \%$.
There is a statistically significant difference in bread consumption related to gender $\left(\chi^{2}=26.534 ; \mathrm{p}=0.003\right)$.

Namely, only female gender does not consummate bread at all (of all the questioned number of subjects). In the same manner, almost a double number of female subjects combine different kinds of bread (61.8\% to 35.5\%). The situation is more evident when it comes to the consumption of blackrye bread in favor of female gender (69.5\% to $28.0 \%)$. In the case of the consumption of half white and white bread the difference in gender is minimal.

The number of subjects who are not aware of the type of fat they use in their diet is almost the same, only $2.7 \%$ of subjects do not use fat in their diet (in the food preparation). Oil is used by $71.3 \%$. Vegetable oil and margarine uses $8.5 \%$ while pork fat is used by $3.8 \%$ respondents. There is a statistically significant difference related to gender $(\chi 2=22.569$; $\mathrm{p}=0.032$ ).

The analysis of using bread spreads in diet in the previous week has shown a significant statistical difference related to gender: $(\chi 2=24.817 ; p=0.016)$. From the overall number of questioned subjects $34.4 \%$ never use bread spreads in their diet, soft cheese is used by $1.7 \%$, pork fat even $11.5 \%$, butter $6.3 \%$ and margarine $26.3 \%$. The number of subjects who never use spreads is higher in female population (70.3\%:27.9\%); similar ratio is in the consumption of pork fat (54.5\%:38.2\%); but soft cheese is used more by male population (75.0\%:25.0\%). Butter and margarine are more used by women: (60.0\%:40.0\% and 60.3\%:38.9\%) respectively.

Although there is no statistically significant difference in the analysis of the form and the way of salting food related to gender, the following conclusions can be made: every fifth subject does not add salt to their food (20.6\%), where a number of female subjects is higher than the number of male subjects (63.6\%:36.4\%). In situations when, according to them the food is not salty enough, $63.3 \%$ of subjects salt the food, more women than men (59.5\%: 40.5\%). Almost always, before they taste the food, $13.8 \%$ salt it, again more women than men (63.6\%:33.3\%).

When drinking coffee is concerned, represented in the number of cups, the results show that there is a statistically significant difference related to gender $(\chi 2=29.742 ; \mathrm{p}=0.04)$. $5.4 \%$ of subjects drink more than five cups of coffee a day and there are a lot more women than men among them. In other cases, in general, female subjects drink coffee more frequently than men; the score is equal in answering the question about if they did not have any coffee the previous week.

In the previous week, more than half of the questioned subjects did not have any coffee (55.8\%), 30.6\% had one cup, 
$6.0 \%$ two cups and $4.6 \%$ had three cups. With the bigger number of cups the number of the subjects who drank them got smaller. The analysis related to gender does not show any statistically significant difference.

For the question of how much sugar they put in one cup of coffee there is no statistically significant difference related to gender but it is encouraging that almost $58 \%$ of subjects consummated tea or coffee in the previous week. With the bigger amount of sugar the number of subjects taking it gets smaller. So, one spoonful of sugar was taken by every fifth subject (21.5\%), two by every seventh (14.4\%), three by only every twenty second (4.4\%), and further on the number of those who use a lot of sugar with their tea or coffee is progressively smaller.

Data about taking sugar with tea have been analyzed and they are similar with slightly altered percentage of certain number of cups of tea. Also, there is no statistically significant difference related to gender.

An especially interesting question was the one whether subjects think about their health when they choose what to eat. $2 \%$ did not give an answer. Every sixteenth subject never considers it (7.9\%). The most frequent answer was that they consider it sometimes, a little less than a half or $45.2 \%$, every third subject or $29.0 \%$ consider it often, and only every sixth does it always (16.3\%). There is no statistical significance related to gender.

\section{DISCUSSION}

Researches in the area of food and dieting have dated since the end of XVIII century, although, the best contribution to the matter has been made by numerous studies from modern times. Numerous studies have been done in our country, questioning the relation of the way and quality of diet on one side and the appearance of certain diseases on the other. ${ }^{4,12}$ The most known are "Health condition, health needs and health care of Serbian population". The analysis was made during the year 2000 with financial and technical support of the World Health Organization (WHO) and the UNICEF, and the research was done by the Institute of public health of Serbia in coordination with the network of institutes and departments for public health as well as the health centers. The results of this research made a foundation for creating Health policy in Serbia in 2002. ${ }^{13}$ A bit later, a new research was done in 2001/2002 under the title "Health condition, health needs and the health care in The Republic of Serbia " with the support of EPOS-Health Consultants.
The subjects of this study were pupils and students, namely the population above 18 years of age, with the idea that it is still possible in this age group to change observed eating disorders successfully and at the same time prevent the appearance of serious, most often chronic diseases that haven 't appeared yet and made damage to health. The second motive for defining causes was in the fact that it was about pupils in Medical school, health department, those who are in the beginning, in the middle or in the end of their professional development. It is only natural to expect that they are the ones who should be well informed and educated about the appropriate eating habits compared to the rest of population. The question still remains if they are educated enough related to eating habits and which prevention measures should be taken to change previous views, habits and behavior related to food consumption. As previously mentioned, bad eating habits as well as smoking are the most frequent causes of severe illnesses with poor or none chances for healing. Therefore, the concept was to compare two imperfectly homogenous (in both samples there is a mix of entities, customs, habits and other characteristics) group aiming to identify the differences and take measures for health protection.

The welfare of a healthier life style acquired in childhood and youth reflects in adult age and will help the maintenance of a good quality of life as well as prevention of the most frequent diseases of modern age - heart and vascular diseases.14 Behavior that is considered risky includes inadequate diet, lack of physical exercise and sedentary life style that can lead to gaining weight, ${ }^{15}$ and also experimenting with cigarettes and smoking at an early age. Children are the most susceptible population group for gaining bad dieting habits, because of parents' busy life and lack of free time they eat outside their homes, mostly fast food. Sufficient intake of energy and nutritious ingredients during childhood and adolescence will not only minimize the risk of health problems such as caries, anemia, growth disorders and becoming overweight, but also postpone or prevent some chronic disease at adult age such as cardiovascular diseases, hypertension, stroke, cancer, diabetes, and osteoporosis. The positive effects of physical activities on young people are associated not only with somatic phenomenon such as blood pressure, lipids in blood, development of bone structure but also with growing confidence and self respect, socialization and proper organization of time and activities.

General lifestyles as well as parents' attitudes to every day habits influence the formation of habits among children and adolescents (even in the period of the greatest rebellion). Therefore, an attitude towards healthy diet, smoking and physical activities coming from family but also from media and public in general, is very important. Behavior of children and adolescents, especially at the age of thirteen 
and above, can be partially explained as a sign of independence and autonomy. In dieting it can often been seen as deciding on vegetarianism, skipping or avoiding meals. The influence on forming dieting habits of children comes from family, school, health care, social organizations, media but also government policy that should support healthy dieting tendencies and provide healthy, tasty and cheap food.

The analysis shows that men have breakfast more rarely than women. The results are equal in the answers to the question if they never have breakfast. In other cases it can be concluded that girls take care of their health more. Unlike the previous results, men have lunch more often than women and the answers to the question if they have an afternoon snack are similar. Men had dinner more often during the previous week. Other questions show differences in gender. Thus, there is no statistically significant difference related to gender when it comes to the consummation of milk, yoghurt, and sour milk, white coffee or cocoa milk as well as in the consummation of boiled potato, rice, pasta, cheese and fish. On the other hand, there is a statistically significant difference in the consummation of pork meat, beef, etc. Namely, men have beef three to five times a week more often than women, or, they never have it in a smaller percentage.

There is no significant difference in the consummation of fresh vegetables and fresh fruit and meat products. Sweet pastries are consummated by a similar number of subjects of both genders and the situation is the same with sweets. But there is a difference in the consummation of sweet non alcoholic drinks. In situations with the highest frequency (6 to 7 times) men do it double more than women, etc. There is no statistically significant difference related to gender in egg consummation, but there is a difference with bread, intake of fat, using bread spreads, while there is no difference in habits related to salting food. Subjects of different gender have shown differences in the way they consume coffee where a significant statistical difference has been observed. Namely, only when it comes to drinking a lot of coffee, male subjects prevail, while in other cases women take over. There are no significant statistical differences related to gender when it comes to sweetening coffee or tea, except for the slight ones. Having in mind that student population has been observed, it is surprising that every sixteenth subject does not think about their health at all, little less than a half consider it only sometimes and every third subject considers it often.

Dietary habits and behavior are related to health in different gender. There is a regularity in having breakfast, which cannot be said about the afternoon snack. In fact, men have breakfast more rarely, while women have snacks more often. The difference is more apparent when it comes to afternoon snacks, men have lunch more often which is the same for the habit of having dinner or supper. Milk and dairy products are not in statistical correlation with gender, the same applies for the habit of consumption of boiled potatoes as well as fried potatoes and rice or pasta, every fifth person consummates chicken 2-3 times a week and the data concerning eating fish are the same and with no difference related to gender.

There is a high frequency in the consumption of pork meat. The consumption of beef gives different situation in different gender. Men consummate beef three to five times a week and they do it twice more than women and in the situation when not doing it at all, women are advancing with almost $20 \%$. Fresh vegetables are almost equally consummated by both genders. The same applies to sweet pastries (cakes and biscuits), as well as sweets (candies and chocolate), men drink more often and with greater frequency sweet non alcoholic drinks (6 to 7 times). Eggs have been consummated with similar frequency in the previous week.

There is a significant statistical difference in bread consumption, namely, only women have stated that they don't eat bread at all and almost twice as them combine different types of bread comparing to men. Only every fortieth person does not use fat in their diet (in food preparation). There is a statistically significant difference related to gender, there are more female subjects who do not use bread spreads. A similar ratio is when it comes to fat or soft cheese, but soft cheese is consummated more by men. Butter and margarine are more used by women. There is no statistically significant difference in the way of salting food. Apart from that, every fifth person does not salt their food, with a greater number of women. When food is not salty enough, $63 \%$ of subjects salt it, more women than men.

More than 5 cups of coffee are consummated by $5.4 \%$ of subjects, more men than women, which goes for the rest of the cases. There is no statistically significant difference in terms of gender when it comes to how much sugar is used for one cup of coffee with similar situation in tea drinking. $2 \%$ of subjects claimed they do not think about their health before taking food, never- every sixteenth subject, etc. A particularly interesting question was the one whether subjects think about their health when they choose what to eat. The most frequent answer was that they consider it sometimes, a little less than a half or $45.2 \%$, every third subject or $29.0 \%$ considers it often, and only every sixth does it always $(16.3 \%)$. 


\section{REFERENCES}

1. Research on the health of the inhabitants of the Republic of Serbia, 2013. The report. Belgrade: Ipsos Strategic Marketing, 2013. (http://www.zdravlje.gov.rs/downloads/2014/jul2014/Jul2014IzvestajPreliminarni.pdf). (in Serbian)

2. National Health Survey Serbia 2016. Key findings. Belgrade: Institute for Public Health "Milan Jovanovic Batut", 2007. (http://www.batut.org.rs/download/publikacije/ NationalHealthSurveySerbia2006.pdf)

3. Nutrition and Overweight. Chapter 19. In: Healthy people 2010 Final review. U.S. Department of health and human services PHS Publication No. 2012-1038. Hyattsville: National Center for Health Statistics, 2012: 1-15. (https://www.cdc.gov/nchs/data/hpdata2010/hp2010_final_review_focus_area_19.pdf)

4. Obradović M, Timotić A, Perunović P, Jocić-Savić K. Risk factors risky behavior and the health of people. Zdravstvena zaštita 2010; 39: 21-9. (in Serbian)

5. Chiuve SE, Willett WC. The 2005 Food Guide Pyramid: an opportunity lost?. Nat Clin Pract Cardiovasc Med 2007; 4: 610-20.

6. FAO and the 17 Sustainable Development Goals. Rome: Food and Agriculture Organization of the United Nations, 2015. (www.fao.org/3/a-i4997e.pdf).

7. Asvall JE. Health for all in the 21st century a policy framework for the WHO European region.Int J Occup Med Environ Health 2000; 13: 5-13.
8. Sun X, Moller H, Evans HS, et al. Residential environment, diet and risk of stomach cancer: a case-control study in Linzhou, China. Asian Pacific J Cancer Prev 2002; 3: 167 72.

9. Grozdanov J, Vuković D, Krstić M, Vančevska Slijepčević B, Milosavljević T. Research on the health of the population of the Republic of Serbia, 2006. Basic results. Belgrade: Ministry of Health of the Republic of Serbia, 2007. (in Serbian)

10. Zdravković D. Obesity in childhood and adolescence. In: Zdravković D, ur. Clinical pediatric endocrinology. Belgrade: Institute for Toextbooks and Teaching Resources, 2001: 349-72. (in Serbian)

11. Švonja Parezanović G, Perić Prkosovački B. Nutritional status and dietary habits of young people. PONS Med J 2014; 11: 48-52. (in Serbian)

12. Šumonja S, Marić M. Frequency and correlations of health risk behaviours of secondary school students in Vojvodina. South Eastern Europe Health Sciences Journal 2012; 2: 106-13.

13. Perunović P, Obradović M, Golijanin R, Timotić B. Economic possibilities to use health care service in Serbia. Zdravstvena zaštita 2009; 38: 47-52. (in Serbian)

14. Vasiljević-Pantelić K, Leštarić Lj, Obradović M, Timotić A. Public health and the life satisfaction . Zdravstvena zaštita 2013; 42: 1-8. (in Serbian)

15. Karnik S, Kanekar A. Childhood obesity: a global public health crisis. Int J Prev Med 2012; 3: 1-7. 